\title{
Self-determination of Personality of Creative Beginning in Choreographic Context
}

Tatiana V. Portnova ${ }^{+*}$

\section{Abstract}

The article analyses the structure of personality self-esteem of representatives of art professions. As an object of the art profession, this research considers the choreographer profession. A feature of the choreographic artist's profession is the directivity on the plastic expression of a given artistic image. This research analyses the process of self-determination of a creative individual in the process of becoming a future professional. The novelty of the research is that choreography is understood not as an innate characteristic of a person, but as an acquired quality. In this research, the researcher shows the methodological techniques, functions and general parameters of the model, which can contribute to the disclosure of creative initiative on the part of the representative of the creative profession. The researchers considered a professional environment that allows the formation of professional qualities in an individual who is in a creative search. A correlation model is presented, which allows speaking about the readiness of an individual for professional selfrealisation.

Keywords: Personality, Self-Appraisal, Creativity, Choreography, Conditions for Implementation.

\footnotetext{
${ }^{+}$Art Department of the Institute of Slavic Culture; Department of Art History; Russian State University named after A.N. Kosygin, 117997, 33-1, Sadovnicheskaya Str., Moscow, Russian Federation *Email: infotatiana-p@mail.ru

(C) 2019 Portnova. This is an Open Access article distributed under the terms of the Creative Commons Attribution License (http://creativecommons.org/licenses/by/2.0), which permits unrestricted use, distribution, and reproduction in any medium, provided the original work is properly cited.
} 


\section{Introduction}

Modern social conditions make special demands to the character of the professional activity of choreography specialist and the professional structure of his/her work in general (Kretov \& Kretova, 2018). One of the ways of achieving this is by carrying out the tasks at the level of high samples from everyday professional activity. Besides, the experience of self-realisation can be gained via:

- the enrichment of basic knowledge and expansion of professional competence general and unique abilities reveal;

- the motivation of one's achievements increases;

- focus on professional self-development activates and adequate self-esteem forms.

Specifics of choreographic activity and its theatrical effectiveness determine non-standard professional activity. Therefore, for selfrealisation, it is necessary to possess special psychological qualities (Portnova, 2018a; Portnova, 2018b). Among professional personal qualities it can be distinguished empathicism, a need for communication, benevolence and disinterestedness, a sense of tact and respect for the audience, low anxiety feeling and confidence in the correctness of one's own actions, stress resistance, diligence, high efficiency, activity and professional competence (Muto, 2016; Portnova, 2018c).

In the field of choreography, professional responsibilities are complemented by a number of features that cannot always be expressed quantitatively or predicted. Such qualities are the ability to transform the art of music in a plastic performance and ability to identify new movements, as well as the elements of expression in the choreographic performance the emotions of a person and the author of the opus (Dekalov et al., 2017; Ivanov, 2018). One should also remember that the choreographic type of art is also characterised by the need to follow a particular type of physical activity which is primarily the basis for the psychological state (Zholmakhanova et al., 2018). In this research, it has been important to single out four interrelated components in the structure of the studied readiness: motivational, cognitive, operating, and reflexive (Verdugo-Perona et al., 2018).

The author attempts to analyse the following: to analyse literary sources which studied the issues of self-determination of a creative personality in the choreographic context and identified interrelated components: motivational, cognitive, operational and reflexive;

- to examine criteria and indicators of readiness of choreographic college specialists;

- to diagnose readiness of choreographic college employees in experimental and control groups of professional selfrealisation (motivational and value criterion);

- to study the particularities of the formation of the investigated quality of readiness of choreographic college specialists for professional self-realisation in the experimental group according to the reflexive-regulatory criterion in comparison before and after the forming stage of the experiment;

- to carry out statistical processing of the experiment's results on the basis of the Statistica 10 computer programme.

- to conclude the need for the introduction of methods in the professional training of choreographic college employees.

In the backdrop of these objectives, the research begins with a brief review of the relevant literature. Following this, the research discusses the materials and methods applied for this research, and finally, it critically discusses the results.

\section{Literature Review}

In this research, it has been important to single out four interrelated components in the structure of the studied readiness: motivational, cognitive, operating, and reflexive. According to 
the selected components, the criteria (motivational-value, cognitive-personal, creative-activity, reflexive-regulatory) have been determined and the indicators of readiness of the choreographic college employees for professional self-realisation (Hamida et al., 2012).

Motivational and value criteria. Its indicators are motives, goals, interests, value orientations, attitude to the profession of choreographic college employees towards professional selfrealisation; the presence of the need for professional self-realisation, the attitude of selffulfilment (Zhang et al., 2006). At the heart of the aspirations are goals - attitudes(constitutive aspect). The subject is going through and regulates such an aspiration (emotional and organisational parameters) providing an intermediate and final result (Chapman \& Mann, 2008). Thus, the self-realisation of the individual, according to this approach, encompasses dynamic, emotional, organisational, motivational, cognitive, competent-personality, constitutive-targeted and reflexive-evaluative components (Barros et al., 2006; Sharma, 2017; Chudnovskaya \& Lipatova, 2018; Koryahin et al., 2019).

The motives of professional self-realisation proceed from the need in it, become conscious and turn into motives - goals that determine the direction of the activity of the self-realisation subject - they represent the future that individuals need to turn into the reality of their life paths through the means of their activity (Mahoney et al., 2017; Parrish, 2007). Values and interests in the process of self-realisation allow a person not only to direct his activity in a certain way but also to make choices and measurements of his life position as well as to organise selfpreservation, self-enrichment and selfdevelopment of an individual throughout his life journey (Bird, 2016). For the activity of the choreographic college employees, the following are the characteristics:

- values reflecting the specifics of the activity, its altruistic nature (rendering help to another person);
- values of ethical responsibility to the chosen profession;

- values related to the need for selfrealisation self-assertion and selfimprovement.

The last characteristic is especially crucial in the context of this research (Golani, 1976). Also, in author opinion, the value attitude to the results of one's own activities, the value attitude to one's own development and the professional self-realisation are significant (Picart, 2013a). It is worth noting that self-realisation of the individual is carried out in the process of personality-oriented learning at the condition of support (Hopwood, 2016). The need for professional self-realisation envisages organising the process of acquiring professional knowledge and skills, the formation of professionally significant personal qualities with their subsequent realisation (Genné \& Anderson, 2011). Analysis of different views on the characteristics of the need for selfrealisation of the individual allowed to identify the main ones:

- the desire and pursuit to learn the sum of the necessary competencies of the future profession;

- social activity of the individual as a basis for improving the need for selfrealisation;

- high moral position and creativity as significant values of the future professional (El Raheb \& loannidis, 2012).

Indeed, professional directivity is defined as a holistic phenomenon with specific characteristics and a component of the direction of one's personality which is manifested in the presence of professionally significant ideals and interests that ensure the purposeful activity of choreographic college employees on the acquisition of knowledge and skills necessary for maintaining the image (Yaari, 2003).

Identification appears as one of the conditions for the formation and implementation of the semantic attitudes of the individual. A sign of identification is the presence of an emotional 
component, the experience of one's personality and the appropriation, interiorisation of specific characteristics of the object of identification (Hopwood, 2016). Identification allows not only to build an aggregate of social relations but also to create one's self (Cortes-Cornax et al., 2013). In the basis of a person's tendency to empathy lies the process of emotional identification, which appears as a necessary condition of the successful empathicalism (Malling, 2013).

Empathy is the highest level of communicativeontological skills of interaction, and, therefore, it expresses an integrative professional feature. The successful building of relationship depends on the level of development of communication skills and personality traits, which, in general, determine the communicative-ontological competence (Balmer et al., 2016). That is why empathy should be considered not only as a professionally important trait but also as a criterion of professionalism (Picart, 2013b).

The structure of empathy consists of three interrelated components:

- cognitive (mental operations, factual knowledge);

- affective (emotional reactions to an object or face);

- conative (motor reactions, behavioural manifestations of a person) (Hahn et al., 2018).

The professional activity of choreographic college employees should cover a moral-ethical dominant. (Muto, 2016; Lee, 2014).

\section{Materials and Methods}

The components of the readiness of the choreographic college employees for professional self-realisation are motivational, cognitive, operation and reflective. They are interrelated and interdependent (Ellis, 1999).

Following the selected components, I defined the criteria and indicators of the readiness of choreographic college employees to the professional self-realisation: motives; goals; interests; value orientations; attitude to the profession and the professional self-realisation; presence of the need for professional self- realisation; the attitude of self-fulfilment; the directivity to the perfect mastery of professional knowledge and professional self-realisation; awareness of the importance of one's activity; the need for professional self-realisation; level of assimilation of the professional knowledge; independence of thinking; and empathy (tendency to empathy).

In the process of analysing the psychological and pedagogical literature, the conditions for effective professional training of choreographic college employees to professional selfrealisation were distinguished which reflect general educational trends in training choreographic college employees in their professional activity.

Experimental methods of implementing the conditions of formation of readiness of choreographic college employees to professional self-realisation involve the development of the studied quality of students according to the following stages: orientationvalue, cognitive-based, constructive-procedural and generalising-correctional. Effective methods of forming the readiness of specialists of the choreographic college for professional selfrealisation are problem tasks. After the experiment, diagnostics of the readiness of choreographic college employees to the professional self-realisation was carried out.

The data obtained allow us to assert significant qualitative and quantitative changes regarding the readiness of choreographic college employees in the experimental group to professional self-realisation. Students, the listeners of advanced training courses and educators-theoreticians of the Kazan choreographic college, took part in the study.

\section{Results and Discussion}

The results of the diagnostics of readiness of choreographic college employees to professional self-realisation according to the motivational and value criterion in the experimental group are presented in Table 1. The results of the control group are presented in Table 2. 


\begin{tabular}{|c|c|c|c|c|c|c|}
\hline Levels & & ligh & Ave & rage & & -ow \\
\hline Indicators: & $\mathrm{n}$ & $\%$ & $\mathrm{n}$ & $\%$ & $\mathrm{n}$ & $\%$ \\
\hline motives, goals, attitude to the profession & 27 & 13.63 & 131 & 66.16 & 40 & 20.2 \\
\hline presence of the need of professional self-realisation & 26 & 13.13 & 129 & 65.15 & 43 & 21.72 \\
\hline directivity to the professional self-realisation & 30 & 15.15 & 135 & 68.18 & 33 & 16.67 \\
\hline awareness of the need for professional self-realisation & 33 & 16.67 & 133 & 67.17 & 32 & 16.16 \\
\hline Average value: & 29 & 14.64 & 132 & 66.67 & 37 & 18.69 \\
\hline
\end{tabular}

Source: Hopwood, 2016

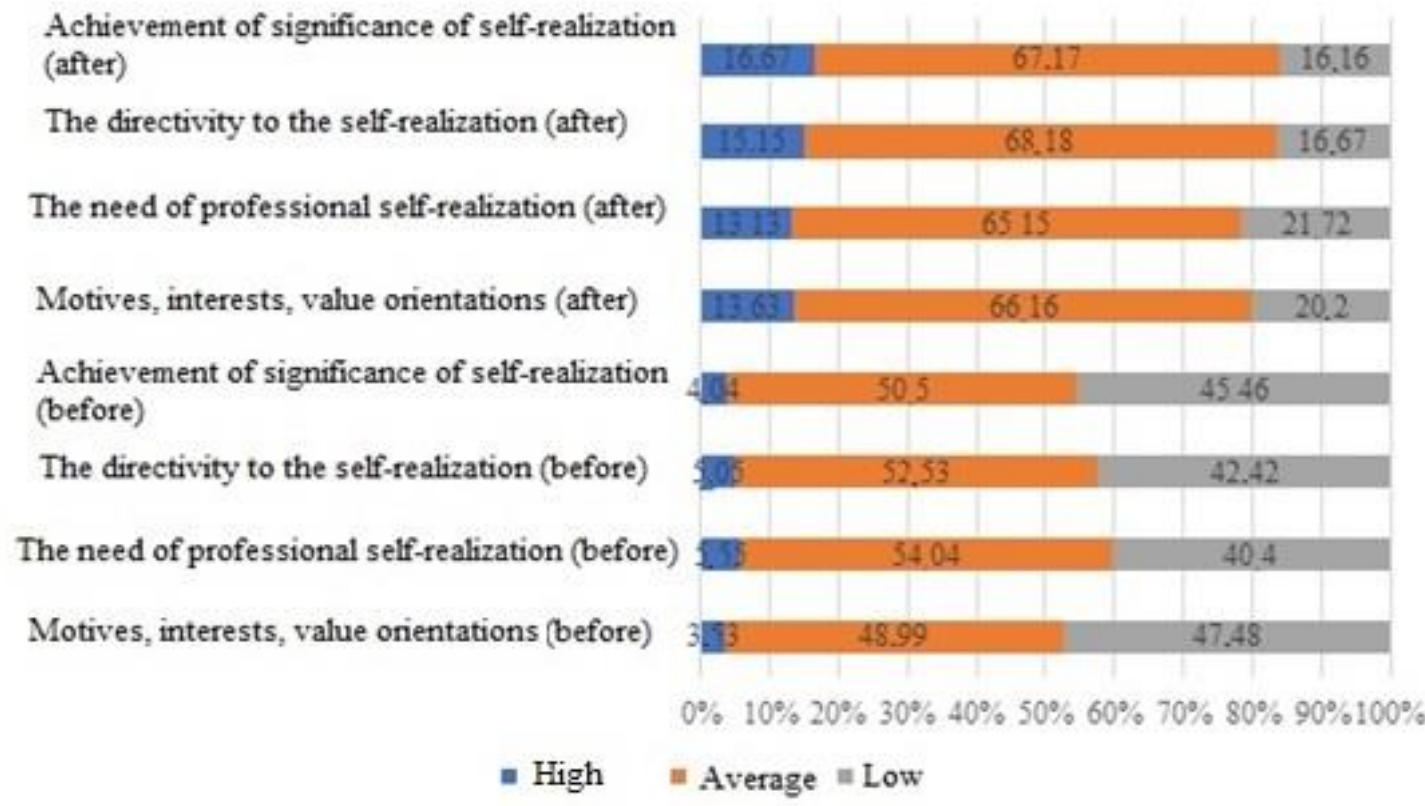

Figure 1: Dynamics of Indicators Development of Motivational and Value Criterion of Readiness of Choreographic College Employees for Professional Self-Realisation

As can be seen from Table 1, in the experimental average level (132employees); $14.64 \%$ (4.54\%) group, on average, $18.69 \%$ (there were $43.94 \%$ ) showed high results (29 respondents) on the of employees have a low level of readiness for results of the final survey. Figure 1 shows the professional self-realisation (37 people) dynamics of the formation of the investigated according to the motivational and value quality according to the motivational and value criterion; 66.67\% (there were 51.52\%) have an criterion.

\begin{tabular}{|c|c|c|c|c|c|c|}
\hline Levels & & gh & & rage & & ow \\
\hline Indicators: & $\mathrm{n}$ & $\%$ & $\mathrm{n}$ & $\%$ & $\mathrm{n}$ & $\%$ \\
\hline motives, goals, attitude to the profession & 9 & 4.64 & 112 & 57.73 & 73 & 37.63 \\
\hline presence of the need for professional self-realisation & 10 & 5.15 & 110 & 56.7 & 74 & 38.14 \\
\hline directivity to the professional self-realisation & 12 & 6.19 & 112 & 57.73 & 70 & 36.08 \\
\hline awareness of the need for professional self-realisation & 9 & 4.64 & 110 & 56.7 & 75 & 38.66 \\
\hline
\end{tabular}

(C) 2019 Portnova. This is an Open Access article distributed under the terms of the Creative Commons Attribution License (http://creativecommons.org/licenses/by/2.0), which permits unrestricted use, distribution, and reproduction in any medium, provided the original work is properly cited. 
According to the results of Table 2, 37.63\% of employees have a low level (73 people); $57.22 \%$ of employees have an average level (111 people), and $5.15 \%$ of employees have a high level (10 people). Figure 2 shows the dynamics of quality according to the motivation and value criterion.

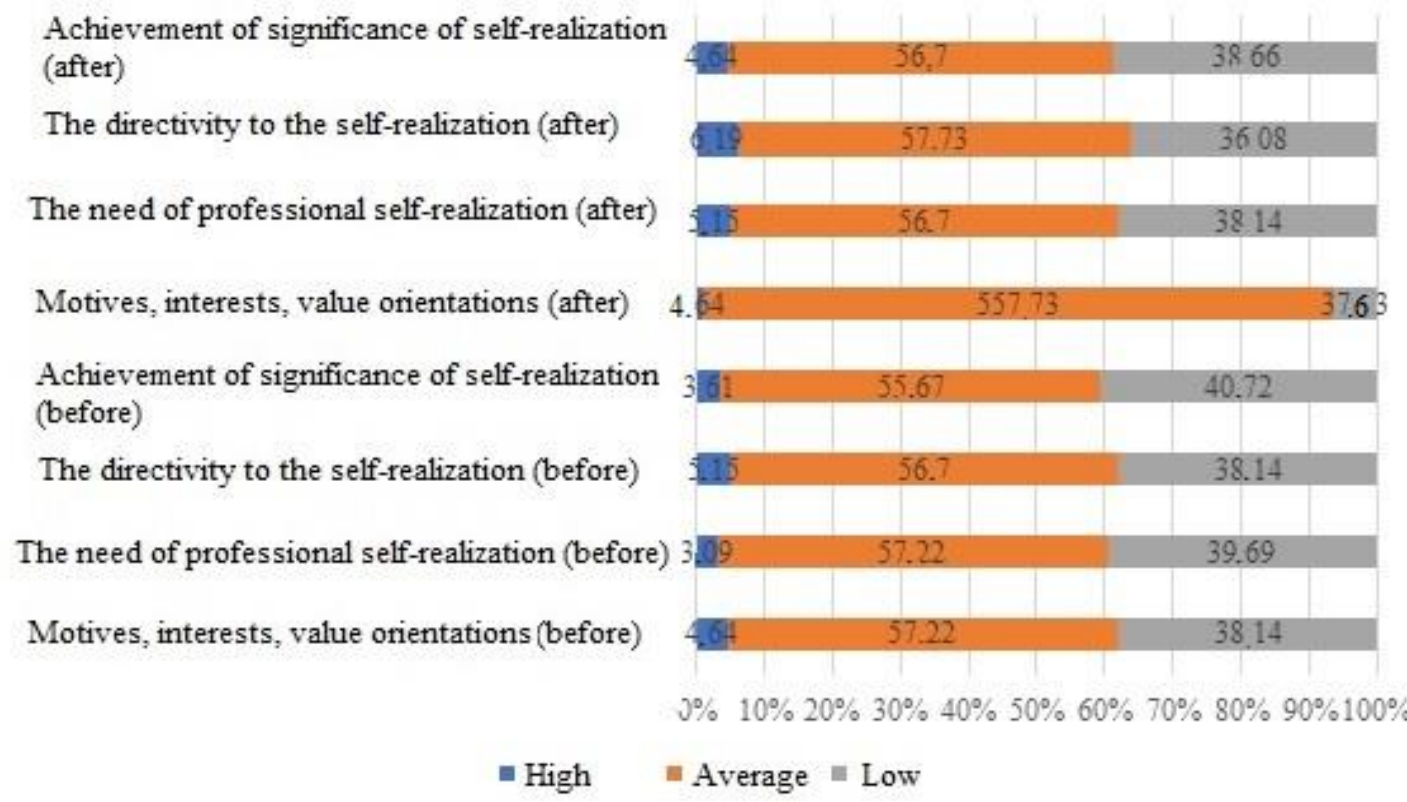

Figure 2: Dynamics of the Development of the Indicators of Motivational and Value Criterion of Readiness of Choreographic College Employees for Professional Self-Realisation in the Control Group

Source: Compiled by the Author

The results of the final diagnostics of the personal criterion in the experimental group are readiness of choreographic college employees presented in Table 3. for professional self-realisation by cognitive-

\begin{tabular}{|c|c|c|c|c|c|c|}
\hline Levels & & ligh & & erage & & ow \\
\hline Indicators: & $\mathrm{n}$ & $\%$ & $\mathrm{n}$ & $\%$ & $\mathrm{n}$ & $\%$ \\
\hline level of mastering the professional knowledges & 29 & 14.64 & 130 & 65.66 & 39 & 19.7 \\
\hline independence of thinking & 30 & 15.15 & 128 & 64.65 & 40 & 20.2 \\
\hline empathicism (tendency to empathy) & 33 & 16.67 & 124 & 62.63 & 41 & 20.7 \\
\hline development of personality qualities & 32 & 16.16 & 126 & 63.64 & 40 & 20.2 \\
\hline Average value: & 31 & 15.66 & 127 & 64.14 & 40 & 20.2 \\
\hline
\end{tabular}

Source: Compiled by the Author

According to the results of Table 3, in the of employees have an average level (127 experimental group $20.2 \%$ (45.96\% of those who people), and $15.66 \%$ (4.04\% of those who participated) of employees have a low level (40 participated) of employees have a high level (31 people); $64.14 \%$ (50\% of those who participated) people). 


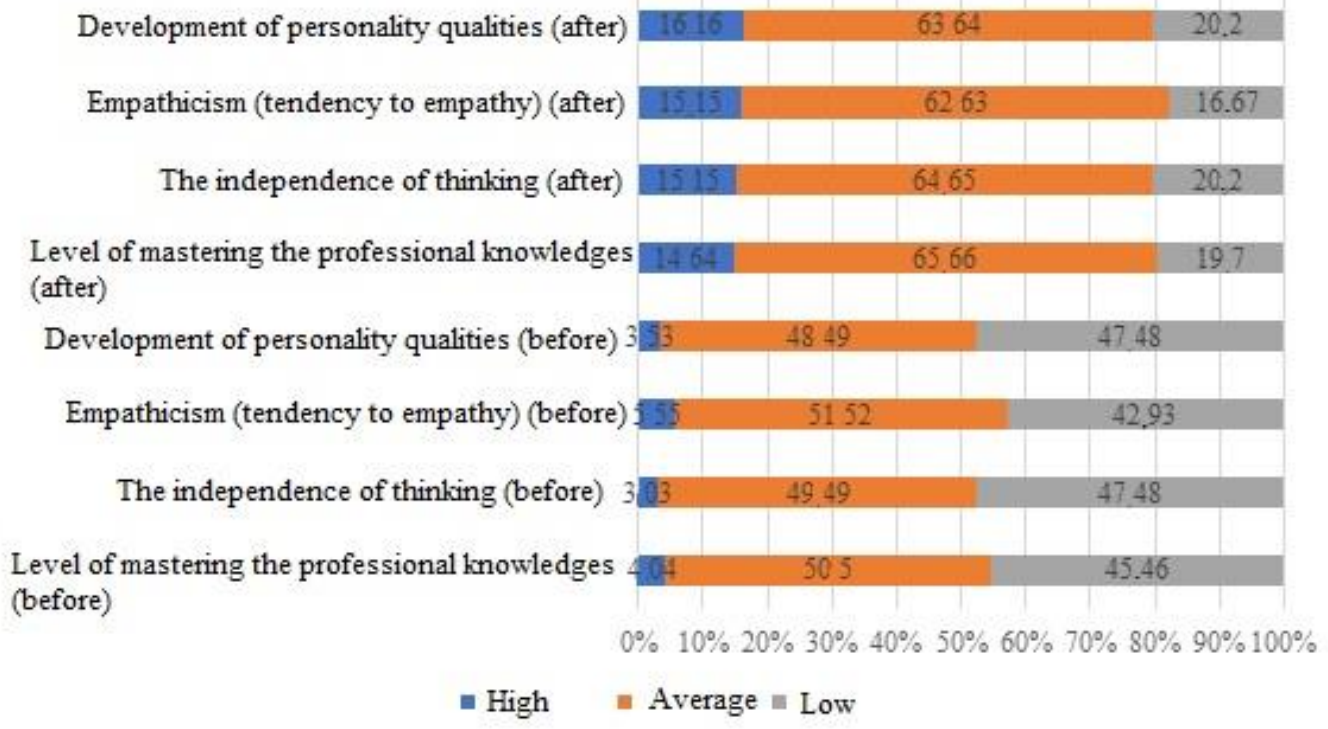

Figure 3: Dynamics of Development of Indicators of the Cognitive-Personal Criterion of Readiness of Choreographic College Employees for Professional Self-Realisation in the Experimental Group Source: Compiled by the Author

Figure 3 shows the dynamics of the quality studied in the control group by the cognitivepersonal criterion. The results of the final diagnostics on the cognitive-personal criterion in the control group are presented in Table 4.

\begin{tabular}{|c|c|c|c|c|c|c|}
\hline Levels & & igh & & rage & & ow \\
\hline Indicators: & $\mathrm{n}$ & $\%$ & $\mathrm{n}$ & $\%$ & $\mathrm{n}$ & $\%$ \\
\hline level of mastering the professional knowledges & 13 & 6.7 & 112 & 57.73 & 69 & 35.57 \\
\hline independence of thinking & 9 & 4.64 & 108 & 55.67 & 77 & 39.69 \\
\hline empathicism (tendency to empathy) & 12 & 6.19 & 109 & 56.18 & 73 & 37.63 \\
\hline development of personality qualities & 10 & 5.15 & 111 & 57.22 & 73 & 37.63 \\
\hline Average value: & 11 & 5.67 & 110 & 56.7 & 73 & 37.63 \\
\hline
\end{tabular}

Source: Compiled by the Author

According to the results of Table 4, in the control group, on average, $37.63 \%$ of employees have a low level of readiness for professional selfrealisation (73 people); $56.7 \%$ of employees have an average level (110 employees), and
$5.67 \%$ of employees showed rather high results (11 respondents).

Figure 4 shows the dynamics of development of the investigated quality in the control group according to the cognitive-personal criterion. 


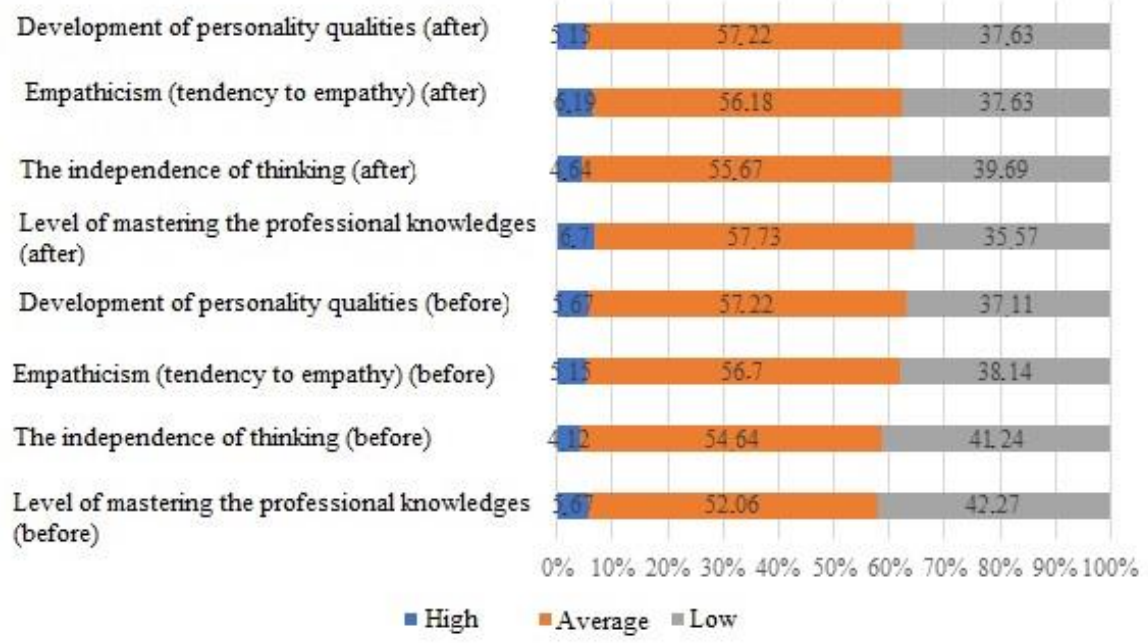

Figure 4: Dynamics of the Development of Indicators of the Cognitive-Personal Criterion of Readiness of Choreographic College Employees for Professional Self-Realisation in the Control Group

Source: Compiled by the Author

\begin{tabular}{|c|c|c|c|c|c|c|}
\hline Levels & & tigh & Av & rage & & ow \\
\hline Indicators: & $\mathrm{n}$ & $\%$ & $\mathrm{n}$ & $\%$ & $\mathrm{n}$ & $\%$ \\
\hline the development of practical professional skills & 33 & 16,67 & 135 & 68,18 & 30 & 15,15 \\
\hline the ability to creatively solve the professional problems & 30 & 15.15 & 131 & 66.16 & 37 & 18.69 \\
\hline the ability to interoperability with spectator & 33 & 16.67 & 134 & 67.68 & 31 & 15.66 \\
\hline independence in quasi-professional activity & 32 & 16.16 & 132 & 66.67 & 34 & 17.17 \\
\hline Average value: & 32 & 16.16 & 133 & 67.17 & 33 & 16.67 \\
\hline
\end{tabular}

The results of the final diagnostics of the readiness of choreographic college employees for professional self-realisation according to the creative activity criterion in the experimental group are presented in Table 5 . Figure 5 shows the dynamics of the studied quality in the control group by the cognitive-personal criterion.

According to Table 6, in the experimental group, after applying the methods of implementation of the conditions for the formation of readiness of choreographic college employees to professional self-realisation, $16.67 \%$ (41.92\%) of employees have a low level of readiness for professional self-realisation (33 people); $67.17 \%$ (54.55\%) of employees have an average level (133 employees), and $16.16 \%$ (3.53\%) of employees showed high results (32 respondents). 


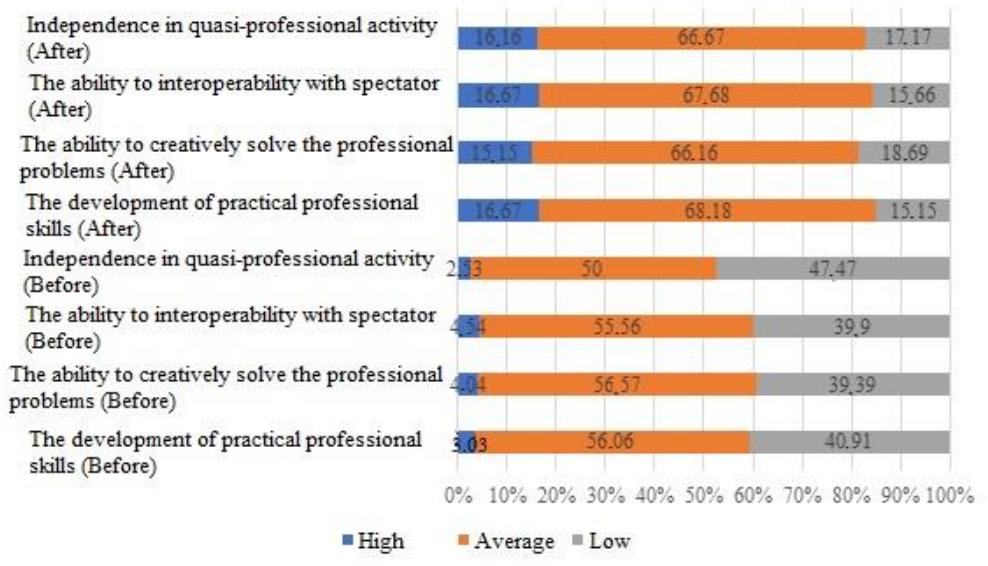

Figure 5: Dynamics of Indicators of Development of Cognitive-Personal Criterion of Readiness of Choreographic College Employees for Professional Self-Realisation in the Experimental Group Source: Compiled by the Author

\begin{tabular}{|c|c|c|c|c|c|c|}
\hline Levels & & igh & Av & rage & & Low \\
\hline Indicators: & $\mathrm{n}$ & $\%$ & $\mathrm{n}$ & $\%$ & $\mathrm{n}$ & $\%$ \\
\hline development of practical professional skills & 13 & 6.7 & 105 & 54.12 & 76 & 39.18 \\
\hline ability to creatively solve the professional problems & 14 & 7.22 & 110 & 56.7 & 70 & 36.08 \\
\hline ability to interoperability with spectator & 10 & 5.15 & 109 & 56.18 & 75 & 38.66 \\
\hline independence in quasi-professional activity & 11 & 5.67 & 104 & 53.61 & 79 & 40.72 \\
\hline Average value: & 12 & 6.19 & 107 & 55.15 & 75 & 38.66 \\
\hline
\end{tabular}

Source: Compiled by the Author

Figure 6 shows the dynamics of development of the studied quality in the control group according to the creative activity criterion in comparison before and after the experiment.

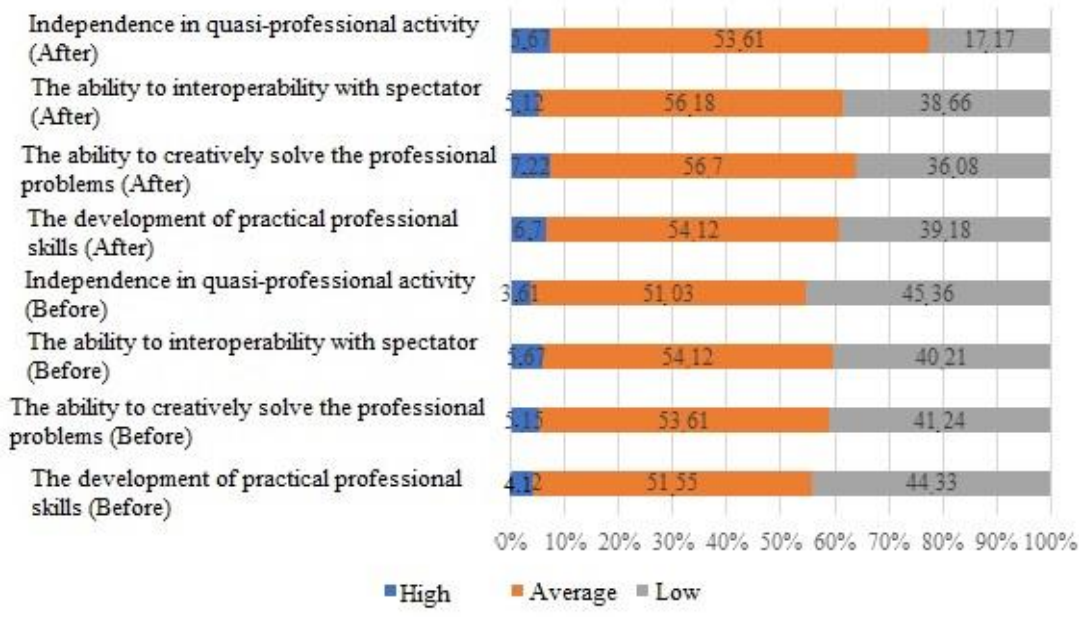

Figure 6: Dynamics of Indicators Development of the Creative Activity Criterion of the Readiness of Choreographic College Employees to Professional Self-Realisation in the Control Group Source: Compiled by the Author 


\begin{tabular}{|c|c|c|c|c|c|c|}
\hline Levels & & ligh & Av & rage & & ow \\
\hline Indicators: & $\mathrm{n}$ & $\%$ & $\mathrm{n}$ & $\%$ & $\mathrm{n}$ & $\%$ \\
\hline ability to self-formation of the professional qualities & 30 & 15.15 & 134 & 67.68 & 34 & 17.17 \\
\hline ability to reflection & 29 & 14.64 & 129 & 65.15 & 40 & 20.2 \\
\hline ability to self-regulation & 32 & 16.16 & 135 & 68.18 & 31 & 15.66 \\
\hline $\begin{array}{l}\text { ability to evaluate and adjust the results of one's own } \\
\text { professional training }\end{array}$ & 29 & 14.64 & 130 & 65.66 & 39 & 19.7 \\
\hline Average value: & 30 & 15.15 & 132 & 66.67 & 36 & 18.18 \\
\hline
\end{tabular}

As can be seen from Table 7, in the experimental group, on average, $18.18 \%(37.88 \%)$ of employees have a low level of readiness for professional self-realisation (36 people); $66.67 \%$ (58.08\%) have an average level (132 employees); $15.15 \%(4.04 \%)$ showed high results (30 respondents). Figure 7 shows the dynamics of the development of the studied quality of

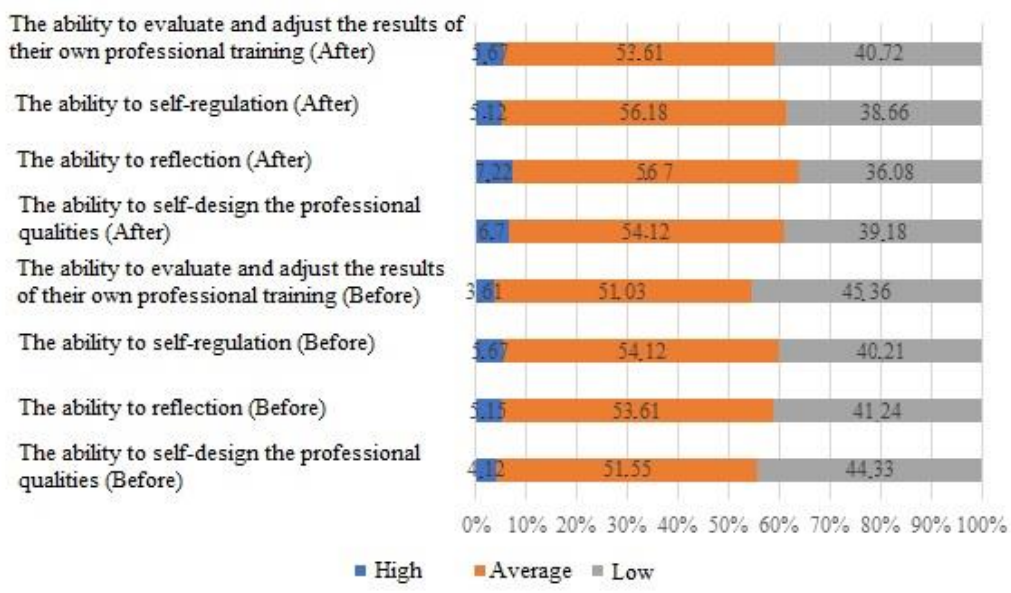

Figure 7: Dynamics of Development Indicators of the Reflexive-Regulatory Criterion of Readiness for Professional Self-Realisation in the Experimental Group Source: Compiled by the Author

\begin{tabular}{|c|c|c|c|c|c|c|}
\hline Levels & & gh & Av & rage & & ow \\
\hline Indicators: & $\mathrm{n}$ & $\%$ & $\mathrm{n}$ & $\%$ & $\mathrm{n}$ & $\%$ \\
\hline ability to self-formation the professional qualities & 13 & 6.7 & 117 & 60.31 & 64 & 32.99 \\
\hline ability to reflection & 9 & 4.64 & 118 & 60.82 & 67 & 34.54 \\
\hline ability to self-regulation & 12 & 6.19 & 115 & 59.27 & 67 & 34.54 \\
\hline $\begin{array}{l}\text { ability to evaluate and adjust the results of their own } \\
\text { professional training }\end{array}$ & 10 & 5.15 & 114 & 58.76 & 70 & 36.08 \\
\hline Average value: & 11 & 5.67 & 116 & 59.79 & 67 & 34.54 \\
\hline
\end{tabular}

Source: Compiled by the Author 
As can be seen from Table 8 , in the control group, on average, $34.54 \%$ of employees have a low level of readiness for professional selfrealisation (67 people); $59.79 \%$ of employees have an average level (116 specialists); 5.67\% of employees showed rather high results (11 respondents). Figure 8 shows the dynamics of development of the studied quality of the control group according to the reflexiveregulatory criterion. The results of the final diagnostics of the readiness of choreographic college employees for professional selfrealisation of the specialists of the experimental and control groups are presented in Table 9.

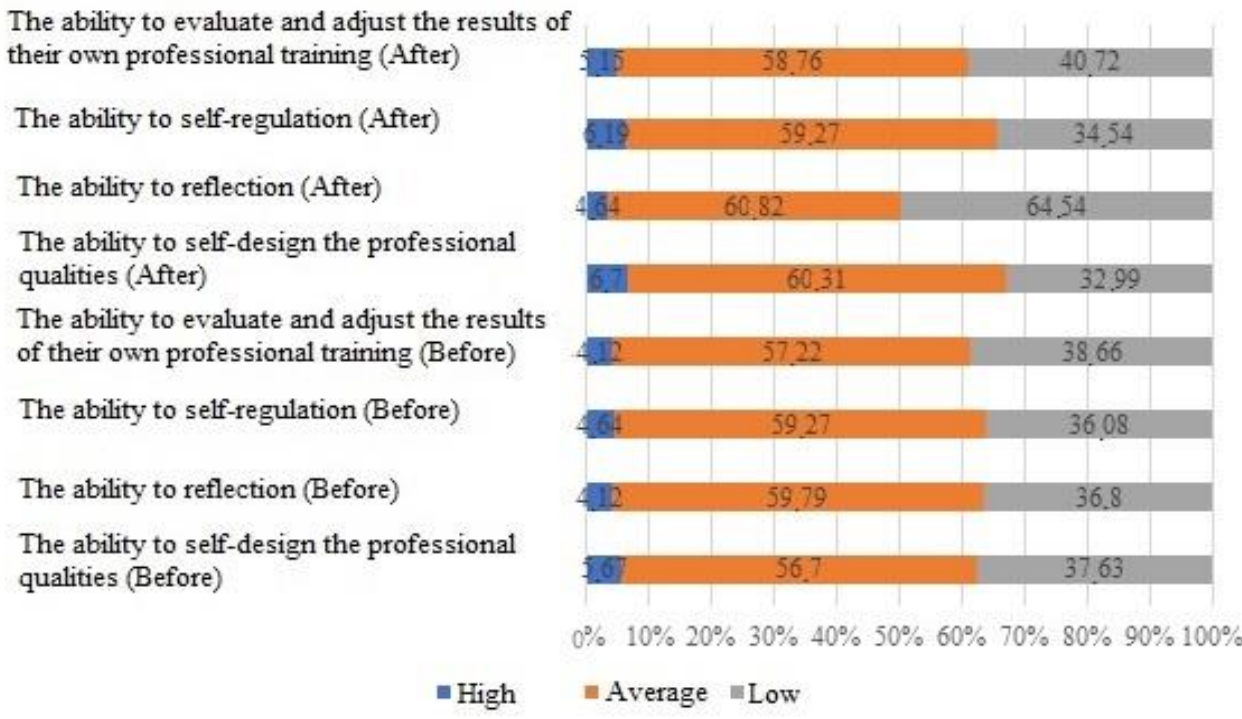

Figure 8: Dynamics of the Development of the Indicators of the Reflexive-Regulatory Criterion of Readiness of Choreographic College Employees for Professional Self-Realisation in the Control Group

\begin{tabular}{|c|c|c|c|c|c|c|c|}
\hline \multirow[t]{3}{*}{ Groups } & \multirow[t]{3}{*}{ Criterion } & \multicolumn{6}{|c|}{ Levels of readiness } \\
\hline & & \multicolumn{2}{|c|}{ High } & \multicolumn{2}{|c|}{ Average } & \multicolumn{2}{|c|}{ Low } \\
\hline & & Abs. & $\%$ & Abs. & $\%$ & Abs. & $\%$ \\
\hline \multirow[t]{5}{*}{ EG (198) } & Motivational and value & 29 & 14.64 & 132 & 66.67 & 37 & 18.69 \\
\hline & Cognitive-personal & 31 & 15.66 & 127 & 64.14 & 40 & 20.2 \\
\hline & Creatively-activity & 32 & 16.16 & 133 & 67.17 & 33 & 16.67 \\
\hline & Reflexively-regulative & 30 & 15.15 & 132 & 66.67 & 36 & 18.18 \\
\hline & Total: & 30 & 15.15 & 131 & 66.16 & 37 & 18.69 \\
\hline \multirow[t]{5}{*}{ CG (194) } & Motivational and value & 10 & 5.15 & 111 & 57.22 & 73 & 37.63 \\
\hline & Cognitive-personal & 11 & 5.67 & 110 & 56.7 & 73 & 37.63 \\
\hline & Creatively-activity & 12 & 6.19 & 107 & 55.15 & 75 & 38.66 \\
\hline & Reflexively-regulative & 11 & 5.67 & 116 & 59.79 & 67 & 34.54 \\
\hline & Total: & 11 & 5.67 & 111 & 57.22 & 72 & 37.11 \\
\hline
\end{tabular}

Table 10 presents the dynamics of the readiness of choreographic college employees for professional self-realisation. 


\begin{tabular}{|c|l|c|c|c|c|c|c|}
\hline & & \multicolumn{3}{c}{ Group } & \multicolumn{3}{c}{ The levels of readiness } \\
& & \multicolumn{3}{c}{ High } & \multicolumn{2}{c|}{ Average } & \multicolumn{2}{c|}{ Low } \\
\hline & & $\mathbf{n}$ & $\%$ & $\mathbf{n}$ & $\%$ & $\mathbf{n}$ & $\%$ \\
\hline 198 & Experimental group after the experiment & 30 & 15.15 & 131 & 66.16 & 37 & 18.69 \\
\hline 194 & The control group after the experiment & 11 & 5.67 & 111 & 57.22 & 72 & 37.11 \\
\hline 198 & Experimental group before the experiment & 8 & 4.04 & 106 & 53.54 & 84 & 42.42 \\
\hline 194 & The control group before the experiment & 9 & 4.64 & 108 & 55.67 & 77 & 39.69 \\
\hline
\end{tabular}

Source: Compiled by the Author

To implement the statistical processing of the present the results of calculations of the results of the formative stage of the experiment, criterion of agreement $\chi^{2}$ for the experimental the Pearson $\chi^{2}$ agreement criterion was used. We group before and after the experiment:

$$
\chi_{E G}^{2}=\frac{(15.5-4.04)^{2}}{4.04}+\frac{(66.16-53.54)^{2}}{53.54}+\frac{(18.69-42.42)^{2}}{42.44}=51.758
$$

We present the results of calculations of the criterion of agreementx 2 for the control group before and after the experiment:

$$
\chi_{K G}^{2}=\frac{(5.67-4.64)^{2}}{4.64}+\frac{(57.12-55.67)^{2}}{55.67}+\frac{(37.11-39.69)^{2}}{39.69}=0.44
$$

The calculated value of the $\chi^{2}$-criterion criterion for comparison of the control group (0.44) was less than the corresponding table value (5.99). The calculated value of the $\chi^{2}$-criterion for comparison of the experimental group (51.758) turned out to be bigger than the corresponding table value (5.99).
Also, for statistical processing of the results of the experiment, it was used Statistica 10 Computer Program. The results of the experiment are shown in Table 11.

\begin{tabular}{|c|c|c|c|c|c|c|c|c|c|c|}
\hline \multicolumn{1}{|c|}{ Table 11: Results of Processing the Primary Data } \\
\hline & $\begin{array}{c}\text { Av. } \\
\text { EG }\end{array}$ & $\begin{array}{c}\text { Av. } \\
\text { CG }\end{array}$ & $\begin{array}{c}\text { T } \\
\text { value }\end{array}$ & $\mathbf{p}$ & $\mathbf{n ~ 1}$ & $\mathbf{n ~ 2}$ & $\begin{array}{c}\text { Mean } \\
\text { deviation }\end{array}$ & $\begin{array}{c}\text { Mean } \\
\text { deviation }\end{array}$ & $\mathbf{F}$ & P \\
& & & & & & & $\mathbf{1}$ & $\mathbf{2}$ & \\
\hline $\mathbf{1}$ & 1.606 & 1.649 & 0.758 & 0.449 & 198 & 194 & 0.577 & 0.558 & 1.063 & 0.671 \\
\hline $\mathbf{2}$ & 1.581 & 1.654 & 1.275 & 0.203 & 198 & 194 & 0.571 & 0.575 & 1.015 & 0.916 \\
\hline $\mathbf{3}$ & 1.616 & 1.618 & 0.042 & 0.967 & 198 & 194 & 0.556 & 0.575 & 1.070 & 0.636 \\
\hline $\mathbf{4}$ & 1.662 & 1.675 & 0.243 & 0.808 & 198 & 194 & 0.553 & 0.560 & 1.024 & 0.867 \\
\hline Total & 1.623 & 1.649 & 0.459 & 0.647 & 198 & 194 & 9.571 & 0.567 & 1.015 & 0.917 \\
\hline
\end{tabular}

Source: Compiled by the Author

In Table 11, the results of statistical data processing of the initial diagnostics of readiness of choreographic college employees for professional self-realisation according to the motivational and value criterion are presented in the first tape (1); further cognitive-personal (2); creative activity (3); reflexive-regulative (4) and in the bottom line - the generalised results. From Table 11, we see that $\mathrm{p}$ is $0.647, \mathrm{t}=0.459$; therefore, there is no reason to refute the null hypothesis of equality of average values. The 
results of the statistical processing after the experiment are shown in Table 12.

\begin{tabular}{|c|c|c|c|c|c|c|c|c|c|c|}
\hline \multirow[t]{2}{*}{ Criteria } & \multicolumn{10}{|c|}{ T-criterion of the independent samplings } \\
\hline & $\begin{array}{l}\text { Av. } \\
\text { EG }\end{array}$ & $\begin{array}{l}\text { Av. } \\
\text { CG }\end{array}$ & $\begin{array}{c}\mathrm{t} \\
\text { value }\end{array}$ & $\mathbf{p}$ & n 1 & n 2 & $\begin{array}{c}\text { Mean } \\
\text { deviation } \\
1\end{array}$ & $\begin{array}{c}\text { Mean } \\
\text { deviation } \\
2\end{array}$ & $\mathbf{F}$ & $\mathbf{P}$ \\
\hline 1 & 1.959 & 1.675 & 4.909 & 0.000 & 198 & 194 & 0.578 & 0.569 & 1.029 & 0.843 \\
\hline 2 & 1.954 & 1.680 & 4.616 & 0.000 & 198 & 194 & 0.598 & 0.576 & 1.077 & 0.603 \\
\hline 3 & 1.995 & 1.675 & 5.449 & 0.000 & 198 & 194 & 0.573 & 0.587 & 1.045 & 0.758 \\
\hline 4 & 1.969 & 1.711 & 4.470 & 0.000 & 198 & 194 & 0.578 & 0.566 & 1.042 & 0.770 \\
\hline Total & 1.965 & 1.685 & 4.774 & 0.000 & 198 & 194 & 0.582 & 0.575 & 1.025 & 0.865 \\
\hline
\end{tabular}

As can be seen from Table $12, \mathrm{p}$ is $0.000, \mathrm{t}=$ 4.774, therefore, there is a reason to refute the null hypothesis of equality of the average values of the EG and CG after the experiment. The dynamics of the EG results before and after the experiment (processed using the Statistica 10 program) are shown in Table 13. From Table 13 we see that $p$ is $0.000, t=6.046$, therefore, there is a reason to refute the null hypothesis of equality of the average values of the EG before and after the experiment.

\section{Table 13: Dynamics of EG Data}

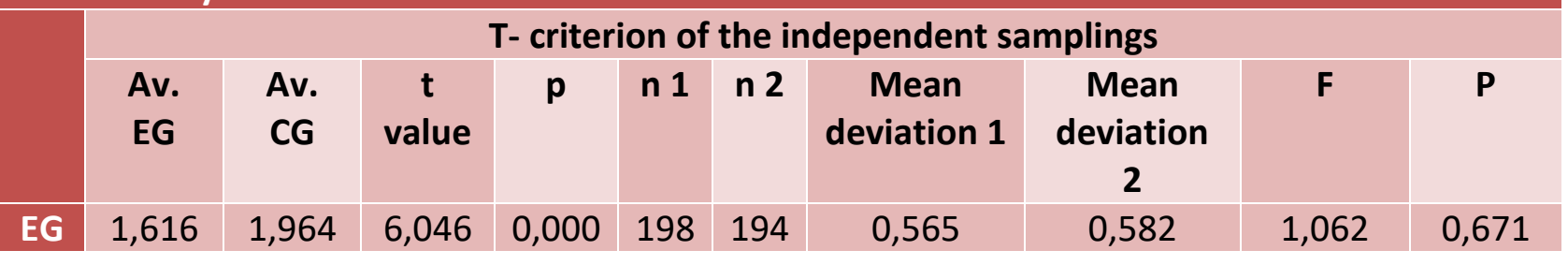

\begin{tabular}{|c|c|c|c|c|c|c|c|c|c|c|}
\hline & \multicolumn{10}{|c|}{ T- criterion of the independent samplings } \\
\hline & $\begin{array}{l}\text { Av. } \\
\text { EG }\end{array}$ & $\begin{array}{l}\text { Av. } \\
\text { CG }\end{array}$ & $\begin{array}{c}\mathrm{t} \\
\text { value }\end{array}$ & $\mathbf{p}$ & n 1 & n 2 & $\begin{array}{c}\text { Mean } \\
\text { deviation } \\
1\end{array}$ & $\begin{array}{c}\text { Mean } \\
\text { deviation } \\
2\end{array}$ & $\mathbf{F}$ & $\mathbf{P}$ \\
\hline CG & 1.649 & 1.685 & 0.622 & 0.534 & 194 & 194 & 0.567 & 0.575 & 1.027 & 0.855 \\
\hline
\end{tabular}

From Table 14, we see that $\mathrm{p}$ is $0.534, \mathrm{t}=0.622$; therefore, there is no reason to refute the null hypothesis of equality of average values of CG before and after the experiment.

\section{Conclusion}

Experimental research confirmed the assumption about the fact that the level of readiness of choreographic college employees for professional self-realisation would increase on condition of the focus of their professional training on professional self-realisation which is ensured by the formation of the motivational attitudes of choreographic college employees.

As our study showed, the methodology for forming the readiness of choreographic college employees for professional self-realisation adequately reflects the justified conditions that ensure the continuity and succession of this process taking into account the possibilities of maintaining the training choreographic college 
employees as well as the forms and methods of their training. The introduction of the methodology in the professional training of choreographic college employees improves its quality and makes it possible to prepare specialists for future work activity by the modern requirements of the society to the employees of the choreographic college.

\section{References}

Balmer, A. S., Bulpin, K., \& Molyneux-Hodgson, S. (2016). Enacting ontologies, failure and time. In Synthetic Biology: A Sociology of Changing Practices. London: Palgrave Macmillan UK. https://doi.org/10.1057/9781137495426_5

Barros, A., Dumas, M., \& Oaks, P. (2006). Standards for web service choreography and orchestration: Status and perspectives. In C.J. Bussler \& A. Haller (Eds.), Business Process Management Workshops, (pp. 6174). Berlin, Heidelberg: Springer Berlin Heidelberg.

Bird, H. A. (2016). Styles of dance and their demands on the body. In Performing Arts Medicine in Clinical Practice (pp. 21-37). Cham: Springer International Publishing.

Chapman, J., \& Mann, P. (2008). Leadership presence: Character development as the choreography of body-mind. In K.T. James \& J. Collins (Eds.), Leadership Learning: Knowledge into Action (pp. 111-130). London: Palgrave Macmillan UK. https://doi.org/10.1057/9780230584075_7

Chudnovskaya, I.N., \& Lipatova, M.E. (2018). Impact of media on shaping ethno-cultural stereotypes in British and Russian young people. Media Watch, 9(3), 426-436.

Cortes-Cornax, M., Ciuciu, I., Dupuy-Chessa, S., Rieu, D., \& Front, A. (2013). Towards the integration of ontologies with service choreographies. In Y. T. Demey \& H. Panetto (Eds.), On the Move to Meaningful Internet Systems: OTM 2013 Workshops (pp. 343352). Berlin, Heidelberg: Springer Berlin Heidelberg.
Dekalov, V., Kristina, G., \& Dina, U. (2017). Cultural experts and communicative capitalism: Transformation of communicative practices. Media Watch, 8(3), 438-450.

El Raheb, K., \& Ioannidis, Y. (2012). A labanotation based ontology for representing dance movement. In $\mathrm{E}$. Efthimiou, G. Kouroupetroglou, \& S.-E. Fotinea (Eds.), Gesture and Sign Language in Human-Computer Interaction and Embodied Communication (pp. 106-117). Berlin, Heidelberg: Springer Berlin Heidelberg.

Ellis, S. C. (1999). The dancer in performance. In The Plays of W.B. Yeats: Yeats and the Dancer (pp. 154-246). London: Palgrave Macmillan UK. https://doi.org/10.1007/9781-349-27224-2_3

Genné, M. D., \& Anderson, C. (2011). Coming alive: Kairos Dance Theatre's dancing heart vital elders moving in community. In P.E. Hartman-Stein \& A. LaRue (Eds.), Enhancing Cognitive Fitness in Adults: A Guide to the Use and Development of Community-Based Programs (pp. 285-299). New York, NY: Springer New York. https://doi.org/10.1007/978-1-4419-06366_18

Golani, I. (1976). Homeostatic motor processes in mammalian interactions: A choreography of display. Perspectives in Ethology, 2, 69134. https://doi.org/10.1007/978-1-46157572-6_2

Hahn, M., Breitenbücher, U., Kopp, O., \& Leymann, F. (2018). Modeling and execution of data-aware choreographies: an overview. Computer Science Research and Development, 33(3), 329-340. https://doi.org/10.1007/s00450-017-0387-y

Hamida, A., Lesbegueries, J., Salatgé, N., \& Lorré, J.-P. (2012). A toolkit for choreographies of services: Modeling, enactment and monitoring. In P. Herrero, $\mathrm{H}$. Panetto, R. Meersman, \& T. Dillon (Eds.), On the Move to Meaningful Internet Systems: OTM 2012 Workshops (pp. 60-63). Berlin, Heidelberg: Springer Berlin Heidelberg. 
Hopwood, N. (2016). Professional learning as attuning, connecting and sensitizing. In Professional Practice and Learning: Times, Spaces, Bodies, Things (pp. 269-304). Cham: Springer International Publishing. https://doi.org/10.1007/978-3-319-261645_9.

Ivanov, D. (2018). The hard problem of consciousness in the context of philosophy of mind in the twentieth century. Philosophical Problems of Information Technologies and Cyberspace, 15(2), 72-91.

Kretov, P., \& Kretova, O. (2018). Philosophy of information, project of narrative ontology and modern picture of the world. Philosophical Problems of Information Technology and Cyberspace, 1(14), 51-72.

Koryahin, V., Blavt, O., Bakhmat, N., Guska, M., Ludovyk, T., Prozar, M., Bodnar, A., Kravets, S., \& Bezgrebelnaya, E. (2019). Differentiated correction of attention abilities of students with chronic diseases during physical education. Journal of Physical Education and Sport, 19, Article number 44, 293-298.

Lee, J. (2014). An intuitive mobile application for notation of group dance floor plan. In C. Stephanidis (Ed.), HCl International 2014 Posters' Extended Abstracts (pp. 349-354). Cham: Springer International Publishing.

Mahoney, L.M., Lawton, B., \& Foeman, A. (2017). Measuring the impact of course modality on student knowledge, performance and communication apprehension in public speaking pedagogy. Media Watch, 8(1), 7-19.

Malling, S.H. (2013). Choreography and performance with deaf adults who have mental illness: Culturally affirmative participatory research. American Journal of Dance Therapy, 35(2), 118-141. https://doi.org/10.1007/s10465-013-9157-y

Muto, D. (2016). Choreography as meshwork: The production of motion and the vernacular. In T. F. DeFrantz \& P. Rothfield (Eds.), Choreography and Corporeality: Relay in Motion (pp. 31-49). London: Palgrave
Macmillan UK. https://doi.org/10.1057/9781-137-54653-1 3

Parrish, M. (2007). Technology in dance education. In L. Bresler (Ed.), International Handbook of Research in Arts Education (pp. 1381-1397). Dordrecht: Springer Netherlands. https://doi.org/10.1007/978-14020-3052-9_94

Picart, C. J. S. (2013a). Introduction: Preliminary remarks. In Critical Race Theory and Copyright in American Dance: Whiteness as Status Property (pp. 1-20). New York: Palgrave Macmillan US. https://doi.org/10.1057/9781137321978_1

Picart, C. J. S. (2013b). Conclusions: Quo Vadis? In Critical Race Theory and Copyright in American Dance: Whiteness as Status Property (pp. 161-174). New York: Palgrave Macmillan US. https://doi.org/10.1057/9781137321978_7

Portnova, T. (2018a). Object-shaped world of ballet in the expositions and funds of theatrical museums of the world: To the question of the study of choreographic sources. Brukenthal. Acta Musei, 13(2), 331340

Portnova, T.V. (2018b). Synthesized nature of fine arts and ballet theater: System analysis of genre development. European Journal of Science and Theology, 14(5), 189-200.

Portnova, T.V. (2018c). Principles and opportunities of the study of pictorial heritage in the practice of choreographic education. Journal of Siberian Federal University - Humanities and Social Sciences, 11(12), 2043-2055.

Sharma, A. (2017). Multiculturalism, diversity and stereotypes: Engaging students with images in media. Media Watch, 8(1), 20-29.

Verdugo-Perona, J. J., Solaz-Portolés, J. J., Sanjosé, V. (2018). Assessment of pre-service primary teachers' pedagogical knowledge in elementary science: effects from science education training. Periodico Tche Quimica, 15(29), 171-183. 
Yaari, N. (2003). Myth into dance: Martha Graham's interpretation of the classical tradition. International Journal of the Classical Tradition, 10(2), 221-242. https://doi.org/10.1007/s12138-003-0009-x

Zhang, S., Li, Q., Yu, T., Shen, X., Geng, W., \& Wang, P. (2006). Implementation of a notation-based motion choreography system. In H. Zha, Z. Pan, H. Thwaites, A. C. Addison, \& M. Forte (Eds.), Interactive
Technologies and Sociotechnical Systems (pp. 495-503). Berlin, Heidelberg: Springer Berlin Heidelberg.

Zholmakhanova, A. B., Tuyakbaev, G. A., Abdrazakov, K., Oralova, G. S., \& Serdali, B. K. (2018). Kazakh emigration and historical significance of memories of Mustafa Shokay. Utopia y Praxis Latinoamericana, 23(82), 111-120. 